\title{
Effect of Diet Dilution Ratio at Early Age on Growth Performance, Carcass Characteristics and Hepatic Lipogenesis of Pekin Ducks
}

-Author(s)

Wu L*

Guo $X$

Fang $Y$

Hubei Key Laboratory of Animal Nutrition and Feed Science

Wuhan Polytechnic University

Hubei, P. R. China

\section{Mail Adress}

\section{Lingying Wu}

Hubei Key Laboratory of Animal Nutrition and Feed Science

Wuhan Polytechnic University

Wuhan, Hubei 430023, P. R. China

Tel: +86-27-83956175

Fax: $+86-27-83956175$

E-mail: xiaowlying@163.com

\section{-Keywords}

Carcass composition, compensatory growth, diet dilution, hepatic lipogenic enzyme activity, Pekin ducks.

\section{-Acknowledgments}

This research was financially supported by the Natural Science Foundation of Hubei Province, China (Project № 2010CBB02901).

\begin{abstract}
This study was conducted to test the hypothesis that proper diet dilution ratio at early age might improve feed conversion ratio (FCR) and reduce body fat deposition of meat-type ducks. One hundred and fifty 1 -day-old male and female White Pekin ducks $(44.5 \pm 1.0 \mathrm{~g})$ were randomly assigned into three treatments with five replicates (pens) of 10 birds each, respectively representing the experimental diets with 0 (control), 40 or $60 \%$ rice hulls inclusion in the basal diet between 8 and $14 \mathrm{~d}$ of age. The basal diet was fed before and after this period. The results showed that diluting the diet with $40 \%$ rice hulls increased ( $p$ $<0.05$ ) feed intake, decreased adjusted (excluding rice hulls) feed:gain and body weight gain of ducks during the diet-dilution period; ducks fed the diet with $40 \%$ rice hulls had better growth rate $(p<0.05)$ during the recovery period (15 to $42 \mathrm{~d}$ of age) and lower adjusted feed conversion ratio $(p<0.05)$ during the entire experimental period (1 to $42 \mathrm{~d}$ of age) than the control birds, but the same body weight ( $p>$ 0.05 ) as the controls at $42 \mathrm{~d}$ of age. The diet diluted with $60 \%$ rice hulls resulted in lower $(p<0.05)$ body weight at market age than the other treatments. The diet with $40 \%$ rice hulls reduced $(p<0.05)$ skin with fat and abdominal fat pad, crude fat content in the carcass and in breast meat, and increased $(p<0.05)$ carcass crude protein at $42 d$ of age. These changes may be explained by the lower $(p<0.05)$ activities of hepatic malic dehydrogenase (MDH), glucose-6-phosphate dehydrogenase (G-6PDH) and fatty acid synthetase (FAS) enzymes both at 14 and $42 \mathrm{~d}$ of age in birds fed the diluted diets relative to the control birds. The results of this study indicate that feeding diets diluted with $40 \%$ rice hulls to Pekin ducks between 8 to $14 \mathrm{~d}$ of age may induce compensatory growth during the following recovery period, and may be used to improve FCR and to reduce body fat deposition at market age.
\end{abstract}

\section{INTRODUCTION}

The world production of duck meat has steadily increased during the last few years. It was 3.78 million tons in 2008 and will continue to grow at a rate in excess of three per cent per annum (FAO2010). Current feeding strategies in growing Pekin ducks should aim at higher body weight gain, breast meat yield, better feed conversion ratio (FCR), and lower fat content of carcasses and cuts (Hall \& Martin, 2006).

Since Wilson \& Obsourn (1960) demonstrated the phenomenon of compensatory growth in poultry, many studies have reported that early feed restriction is beneficial for improving feed efficiency and decreasing fat content and production costs in broilers (Zubair \& Leeson, 1994; Nielsen et al., 2003; Mohebodini et al., 2009). However, studies in literature have shown great variability of data regarding early feed restriction in broilers. This inconsistency seems to be related to 
several factors, both quantitative or qualitative, such as severity and duration of feed restriction, bird strain and sex, age, period and energy level of refeeding (Zubair \& Leeson, 1996; Lippens et al., 2000, Downs et al., 2006).

Ducks are a poultry species as well as chickens, but ducks are waterfowl, and therefore present different digestive physiology, body composition and growth rate as compared with chickens (Siregar \& Farrell, 1980). Pekin duck carcasses contain about 30\% fat whereas broiler carcasses have 15\% fat at market age (Plavnik et al., 1982). When properly fed, a fifty-gram, oneday-old duck presents a feed efficiency of $45 \mathrm{~g}$ of body weight gain per $100 \mathrm{~g}$ of feed intake and 3,100 g body weight at $42 \mathrm{~d}$ of age, while a thirty-eight-gram, oneday old broiler chicken is capable of a feed efficiency of $56 \mathrm{~g}$ of body weight gain per $100 \mathrm{~g}$ of feed intake and 2,100 g body weight at 42-d old (Adeola, 2006). Zhou et al. (2000) confirmed that not only MDH but also G-6-PDH are NADPH-generating primary enzymes of hepatic fatty acid synthetic method in growing Pekin ducks compared with only $\mathrm{MDH}$ in chickens.

Compensatory growth is referred to as the rapid weight gain that usually follows a period of reduced nutrient intake of an animal when it is placed back on a high quality diet. Unfortunately, limited research had been conducted to evaluate the potential use of early feed restriction on Pekin ducks. Tan \& Ohtani (2000) carried out experiment to compare the effect of different feed restriction regimes between 8 to 14 days of age on performance, carcass composition, and lipid metabolism of male Pekin ducks and concluded that early feed restriction could be used to improve the growth performance and carcass traits of meat-type ducks.

In various feed restriction regimes, it was observed that diet dilution at early age has the advantage of practical application, and it is an easy way to induce growth retardation, but it may impair upon animal welfare (Hassanabadi \& Nassiri Moghaddam, 2006; Rezaei et al., 2006). Therefore, the aim of the present trial was to examine the effect of diet dilution ratio with rice hulls on growth performance, carcass characteristics and composition, and hepatic lipogenesis of Pekin ducks.

\section{MATERIALS AND METHODS}

\section{Birds and experimental design}

A total of 150 one-d-old male and female White Pekin ducks $(44.5 \pm 1.0 \mathrm{~g})$ provided by the local hatchery (Wuhan Chunjiang Poultry Co., Ltd., China) were randomly allocated into three treatments with 5 pens (replicates) of 10 ducks. The pens were $200 \times 120 \times 70$ $\mathrm{cm}$ (length $\times$ width $\times$ height) with raised wire floor. All ducks were fed with starter diet from 1 to $7 \mathrm{~d}$ of age. At $8 \mathrm{~d}$ of age, ducks from three treatments were fed to the experimental diets, which consisted of the starter diet diluted, respectively, with 0 (control), 40 or $60 \%$ rice hulls (starter diet: rice hull ratios of 1:0, 3:2 and 2:3) until $14 \mathrm{~d}$ of age. After this period, all ducks were reared with a grower diet up to $42 \mathrm{~d}$ of age. The starter and grower diets were formulated to meet the nutrient requirements according to NRC (1994) (Table 1). Birds were given free access to mash feed and fresh water at all times. The lighting program and temperature control were applied according to normal management practices. All procedures were approved by Hubei Province Institutional Animal Care and Use Committee.

Table 1- Ingredient composition and nutrient levels of the basal diets (as fed).

\begin{tabular}{|c|c|c|}
\hline Ingredients(\%) & $\begin{array}{l}\text { Starter } \\
\text { (d 1-14) }\end{array}$ & $\begin{array}{l}\text { Grower } \\
\text { (d 15-42) }\end{array}$ \\
\hline Maize & 58.23 & 65.43 \\
\hline Soybean meal & 36.17 & 28.40 \\
\hline Soybean oil & 2.03 & 2.66 \\
\hline Limestone & 1.20 & 1.20 \\
\hline Dicalcium phosphate & 1.40 & 1.40 \\
\hline salt & 0.3 & 0.3 \\
\hline DL-Methionine & 0.17 & 0.17 \\
\hline Choline chloride $50 \%$ & 0.1 & 0.1 \\
\hline Vitamin and trace mineral premix ${ }^{1}$ & 0.4 & 0.4 \\
\hline \multicolumn{3}{|l|}{ Calculated nutrient levels } \\
\hline $\mathrm{ME}^{2}, \mathrm{MJ} / \mathrm{kg}$ & 12.13 & 12.55 \\
\hline Crude protein, g/kg & 210 & 180 \\
\hline Methionine, g/kg & 5.0 & 4.0 \\
\hline Cystine, g/kg & 3.6 & 3.2 \\
\hline Lysine, $\mathrm{g} / \mathrm{kg}$ & 11.0 & 9.0 \\
\hline Calcium, g/kg & 8.8 & 8.6 \\
\hline Nonphytate phosphorus, g/kg & 3.9 & 3.8 \\
\hline \multicolumn{3}{|c|}{$\begin{array}{l}1 \text { - Content of vitamins and minerals in diet per } \mathrm{kg} \text { are as follow: } 8,000 \\
\text { IU retinyl acetate; } 3,000 \mathrm{IU} \text { cholecalciferol; } 20 \mathrm{IU} \text { DL- } \alpha \text {-tocopheryl acetate } \\
2 \mathrm{mg} \text { menadione sodium bisulfite; } 1.5 \mathrm{mg} \text { thiamin mononitrate; } 8 \mathrm{mg} \\
\text { riboflavin; } 3 \mathrm{mg} \text { pyridoxine hydrochloride; } 0.02 \mathrm{mg} \text { cobalamin; } 10 \mathrm{mg} \\
\text { calcium-D-pantothenate; } 50 \mathrm{mg} \text { nicotinic acid; } 1 \mathrm{mg} \text { folic acid; } 0.2 \mathrm{mg} \\
\text { biotin. Cu (as copper sulfate), } 10 \mathrm{mg} \text {; Fe (as ferrous sulfate), } 60 \mathrm{mg} \text {; Mr } \\
\text { (as manganous sulfate), } 80 \mathrm{mg} \text {; Zn (as zinc oxide), } 60 \mathrm{mg} \text {; I (as potassium } \\
\text { iodide), } 0.2 \mathrm{mg} \text {; Se (as sodium selenite), } 0.3 \mathrm{mg} \text {. } 2 \text { - Calculated according } \\
\text { to the AME of chickens. }\end{array}$} \\
\hline
\end{tabular}

Ducks were weighed at $7 d, 14 d$ and $42 \mathrm{~d}$ of age. Feed offered and refused per replicate were daily recorded. Body weight gain, feed intake and feed 
conversion ratio (FCR) were calculated. No mortality was observed in any of the treatments during the whole experimental period.

\section{Sample preparation and analysis}

At $14 \mathrm{~d}$ and $42 \mathrm{~d}$ of age, 10 ducks per treatment (1 male and 1 female per pen), with body weight close to the mean of each pen, were sacrificed by decapitation. The liver and breast meat were carefully removed, quickly snap-frozen in liquid nitrogen, and then stored at $-80^{\circ} \mathrm{C}$ for analysis.

At $42 \mathrm{~d}$ of age, another 10 ducks in each treatment were slaughtered for carcass analysis. After feed deprivation overnight, two birds (one male and one female) were randomly selected from each pen, individually weighed, and sacrificed by cervical dislocation. After bleeding, carcasses were manually plucked and eviscerated. Abdominal fat (including mesenteric fat), breast meat (including the muscles pectoralis major and pectoralis minor), leg meat (including thigh and drumstick), and skin with fat were manually excised and weighed, and then returned to the carcass. The eviscerated carcass with the gastrointestinal tract (washed of its contents) and viscera, except for blood, feces and feathers, were weighed and frozen at $-30^{\circ} \mathrm{C}$ until further tissue composition assay.

All weights, including eviscerated carcass, breast meat, leg meat, skin with fat, and abdominal fat, were expressed as a percentage relative to live weight before slaughter.

Moisture, crude fat, crude protein and crude ash contents of the eviscerated carcasses and breast meat were analyzed by AOAC methods (1984).

Liver analyses were conducted according to Tan \& Ohtani (2000). The hepatic activities of MDH, G-6-PDH, and FAS were determined according to the methods of Ochoa (1955), Lohr \& Waller (1974), and Gibson et al. (1972), respectively. Protein concentration of the solutions used for enzyme assay was determined by Coomassie brilliant blue method, using a protein assay kit (Nanjing Jiancheng Technology Co., Ltd., China). Enzyme activities were expressed in nanomole of NADPH production (MDH and G-6-PDH) or NADPH consumption (FAS) per min per mg protein at 37.

\section{Statistical analysis}

All data were statistically analyzed by a one-way ANOVA using the GLM procedure of SAS software program (SAS, 2000) as a completely randomized design. Any significant differences were further analyzed by Duncan's multiple-range test. All statements of significance were based on probability of 0.05 .

\section{RESULTS AND DISCUSSION}

\section{Growth performance}

During the period of dietary dilution (8 to $14 \mathrm{~d}$ of age), birds fed the diet diluted with $40 \%$ rice hulls consumed more $(p<0.05)$ feed than the control birds (Table 2). This finding was in agreement with Zubair \& Leeson (1994), who reported hypertrophy of the digestive tract associated with higher feed intake relative to body weight in restricted chickens. The feed intake of the group fed $60 \%$ rice hulls was lower $(p<$ 0.05 ) than that in the other treatments, which might be due to the side-effect of rice hull. The adjusted feed intake (excluding rice hulls, assumed to be indigestible), as well as body weight gain, were reduced $(p<0.05)$ with increasing dilution rates. Surprisingly, adjusted FCR of ducks fed the diet with $40 \%$ rice hull was the lowest $(p<0.05)$ of the three treatments. There was a transient decrease in basal metabolic rate of feedrestricted birds, leading to less energy required for maintenance (Rincon \& Leeson, 2002; Tolkamp et al., 2005). The lower basal metabolic rate might be one of the reasons of the reduced FCR presented by the restricted ducks in the present study.

During the period of 15 to $42 \mathrm{~d}$ of age (refeeding period), the feed intake of the birds in the treatment with $40 \%$ dilution ratio was not different $(p>0.05)$, but weight gain was higher $(p<0.05)$ and FCR lower $(p<$ 0.05 ) relative to the control birds. Apparently, ducks fed the diet with the $40 \%$ dietary dilution ratio presented compensatory growth. This is consistent with the findings of Govaerts et al. (2000), Tumova et al. (2002) and Tolkamp et al. (2005), whose reports concluded that a period of slow growth, followed by compensation until regular market weight, reduced maintenance costs and improved feed efficiency. McMurtry et al. (1988) stated that changes in weight gain composition, higher efficiency of energy utilization and reduction in maintenance requirements, or a combination of these factors, contributed to the phenomenon of compensatory growth. After the restriction period, feed intake and weight gain of ducks fed the $60 \%$ dilution ratio diet were the lowest $(p<0.05)$ of all three treatments, similar to the period of dietary dilution. It seemed that ducks with $60 \%$ dietary dilution ratio were not able to present compensatory growth.

During the entire experimental period ( 1 to $42 \mathrm{~d}$ of age), adjusted feed intake of birds eating the diet 
Table 2 - Effect of early diet dilution ratio on growth performance of Pekin ducks.

\begin{tabular}{|c|c|c|c|c|}
\hline Treatments & $0 \%$ rice hulls & $40 \%$ rice hulls & $60 \%$ rice hulls & SEM \\
\hline \multicolumn{5}{|c|}{ Feed intake, g/duck } \\
\hline d $8-14^{*}$ & $453.2 b$ & $483.2 \mathrm{a}$ & $405.5 c$ & 7.9 \\
\hline d $8-14^{* *}$ & $453.2 \mathrm{a}$ & $289.9 b$ & $162.2 \mathrm{C}$ & 6.8 \\
\hline d $15-42$ & $5612.4 a$ & $5580.0 a$ & $4238.1 b$ & 32.2 \\
\hline d $1-42 *$ & $6259.6 a$ & $6257.2 a$ & $4837.6 b$ & 35.8 \\
\hline d $1-42$ ** & $6259.6 a$ & $6063.9 b$ & $4594.3 c$ & 36.6 \\
\hline \multicolumn{5}{|c|}{ Body weight gain, g/duck } \\
\hline d 8-14 & $354.1 \mathrm{a}$ & $279.5 b$ & $119.7 c$ & 8.8 \\
\hline d $15-42$ & $2227.6 b$ & $2310.4 a$ & $1883.6 \mathrm{c}$ & 14.4 \\
\hline d $1-42$ & $2760.4 a$ & $2768.9 a$ & $2182.3 c$ & 12.0 \\
\hline \multicolumn{5}{|c|}{ Feed: gain, $(g / g)$} \\
\hline d $8-14^{*}$ & $1.28: 1 \mathrm{c}$ & $1.73: 1 b$ & $3.39: 1 a$ & 0.02 \\
\hline d $8-14^{* *}$ & $1.28: 1 b$ & $1.04: 1 \mathrm{C}$ & $1.36: 1 \mathrm{a}$ & 0.02 \\
\hline d $15-42$ & $2.52: 1 a$ & $2.41: 1 b$ & $2.25: 1 \mathrm{C}$ & 0.01 \\
\hline d $1-42^{*}$ & $2.27: 1 a$ & $2.26: 1 a$ & $2.22: 1 b$ & 0.01 \\
\hline d $1-42^{* *}$ & $2.27: 1 a$ & $2.19: 1 b$ & $2.10: 1 \mathrm{C}$ & 0.01 \\
\hline
\end{tabular}

* - feed intake and feed: gain with the rice hull ${ }^{* *}$ feed intake and feed: gain without the rice hull. $a, b-$ means with different superscripts in the same row are significantly different $(p<0.05)$.

diluted at $40 \%$ was reduced ( $p<0.05$ ) compared with the control birds. Body weight gain was similar ( $p>0.05$ ) between birds fed the starter diet diluted at $40 \%$ after resuming eating the and birds fed the regular undiluted starter diet. As a result, the adjusted

Table 3 - Effect of early diet dilution ratio on carcass characteristics and chemical composition of Pekin ducks at $42 \mathrm{~d}$ of age.

\begin{tabular}{|c|c|c|c|c|}
\hline Treatments & $0 \%$ rice hulls & $40 \%$ rice hulls & $60 \%$ rice hulls & SEM \\
\hline Live weight (g) & 2810 & 2803 & 2228 & 51.7 \\
\hline \multicolumn{5}{|c|}{ carcass characteristics ( $\%$ of live weight) } \\
\hline Eviscerated carcass & 72.51 & 71.57 & 71.02 & 0.67 \\
\hline Breast meat & 10.70 & 10.61 & 10.50 & 0.18 \\
\hline Leg meat & 8.00 & 7.95 & 7.86 & 0.10 \\
\hline Skin with fat & $23.57 a$ & $20.34 b$ & $19.61 c$ & 0.22 \\
\hline Abdominal fat & $1.46 a$ & $1.38 b$ & $1.33 c$ & 0.01 \\
\hline \multicolumn{5}{|c|}{ Relative weight ( $\%$ of carcass ) } \\
\hline Moisture & $54.7 \mathrm{~b}$ & $55.1 \mathrm{~b}$ & $57.0 \mathrm{a}$ & 0.8 \\
\hline Crude fat & $27.6 \mathrm{a}$ & $25.8 b$ & $24.1 c$ & 0.5 \\
\hline Crude protein & $15.2 b$ & $16.6 \mathrm{a}$ & $16.3 \mathrm{a}$ & 0.4 \\
\hline Crude ash & 2.5 & 2.5 & 2.6 & 0.2 \\
\hline \multicolumn{5}{|c|}{ Relative weight (\% of breast meat) } \\
\hline Moisture & 75.8 & 76.1 & 76.4 & 1.0 \\
\hline Crude fat & $2.9 \mathrm{a}$ & $2.2 \mathrm{~b}$ & $2.0 \mathrm{~b}$ & 0.2 \\
\hline Crude protein & 20.8 & 21.2 & 21.0 & 0.4 \\
\hline Crude ash & 0.5 & 0.5 & 0.6 & 0.1 \\
\hline
\end{tabular}

$a, b$ - means with different superscripts in the same row are significantly different $(p<0.05)$.
FCR was reduced $(p>0.05)$. Similarly, the compensatory growth exhibited by restricted broilers allowed the recovery of body weight at slaughter age and sometimes reaching higher body weight than that of birds fed ad libitum (Plavnik \& Hurwitz, 1990). However, these results are in contrast with the findings of Khetani et al. (2008), who applied three treatments (control, one week of feed dilution and two weeks of feed dilution) in their experiment and reported there was no significant difference in feed conversion ratio among broilers. Though adjusted FCR of ducks fed the diet with $60 \%$ dilution ratio was the lowest $(p<0.05)$, this may have resulted from the low body weight of these birds at slaughter age.

\section{Carcass characteristics and chemical composition}

Eviscerated carcass, breast meat and leg meat weights, expressed as a percentage of live weight were not affected $(p>0.05)$ by feed dilution (Table 3 ). These results are consistent with those of Zubair \& Leeson (1994), Lippens et al. (2000), and Rezaei et al. (2006), who did not demonstrate any effect of feed dilution on dressing proportion or on other carcass characteristics in broilers.

In the present trial, skin with fat and abdominal fat weights of feed-restricted birds at $42 \mathrm{~d}$ of age were significantly decreased $(p<0.05)$ as dilution rate increased (Table 3). Literature presents a wide great variability of data relative to the effect of early feed restriction on fat deposition. Plavnik \& Hurwitz (1985) mentioned that the substantial reduction in the size of the abdominal fat pad of broilers was not influenced by nutrition during refeeding. Cabel \& Waldroup (1990) also reported reductions in abdominal fat pad due to early life feed dilution, but a small reduction in nal body weight. Zubair \& Leeson (1996) similarly showed that feed-restricted birds usually presented a numerically smaller abdominal fat pad at market age than the control birds. On the other hand, Zhan et al. (2007) reported that feed dilution increased abdominal fat pad at $63 \mathrm{~d}$ of age. 
There was no significant difference $(p>0.05)$ in carcass moisture, ash and breast meat between ducks fed the diet with $40 \%$ dilution ratio and the control ducks (Table 3). The diet with $40 \%$ dilution ratio increased $(p<0.05)$ carcass crude protein and decreased $(p<0.05)$ crude fat and breast meat. The result of the present study is in agreement with $\mathrm{Yu}$ et al. (1990), who reported that birds under restriction had lower carcass fat. This is in contrast with the findings of Lippens et al. (2002), who reported that total protein and total fat content (\% entire animal including feathers) were not influenced by feed restriction.

\section{Hepatic lipogenic enzyme activities}

In avian species, the liver is the major site of lipogenesis, although the bone marrow, adipose tissue and skin make minor contributions (Zhong et al., 1995). Hepatic lipogenesis is highly responsive to changes in the diet (Hillgartner et al., 1995; Kersten, 2001). The nutritional status of the bird, as determined by the amount and composition of feed consumed, dramatically affects hepatic lipid metabolism (Hillgartner et al., 1995).

In this experiment, the activities of G-6-PDH, MDH and FAS in liver were reduced $(p<0.05)$ both at 14 $\mathrm{d}$ and $42 \mathrm{~d}$ of age as dietary dilution ratio increased (Table 4). These results were consistent with those of Tan \& Ohtani (2000), who fed ducks between 8 to 14 days of age with a diluted diet containing about $50 \%$ rice hulls, and observed that carcass fat content decreased at 14 and 49 days of age. Moreover, those authors found that the activities of hepatic FAS and acetyl-CoA carboxylase (ACC) also were reduced at the end of 7 days feed restriction and tended to be further reduced at 49 days of age when compared with control ducks.

The effects of diet dilution on the activities of

Table 4 - Effects of early diet dilution ratio on hepatic adipose enzyme activities in Pekin ducks at $14 \mathrm{~d}$ and $42 \mathrm{~d}$ of age.

\begin{tabular}{|c|c|c|c|c|c|c|}
\hline \multirow{3}{*}{ Treatments } & \multicolumn{6}{|c|}{ Hepatic adipose enzyme activitiesnmol $/ \mathrm{min} / \mathrm{mg}$ protein } \\
\hline & \multicolumn{3}{|c|}{$14 \mathrm{~d}$ of age } & \multicolumn{3}{|c|}{$42 \mathrm{~d}$ of age } \\
\hline & $\mathrm{MDH}^{1}$ & G-6-PDH ${ }^{2}$ & FAS $^{3}$ & MDH & G-6-PDH & FAS \\
\hline $0 \%$ rice hulls & $240.0 a$ & 125.0a & $59.4 a$ & $288.4 a$ & $176 a$ & $78.4 a$ \\
\hline $40 \%$ rice hulls & $188.2 b$ & $83.5 b$ & $44.7 \mathrm{~b}$ & $240.1 b$ & $121.1 b$ & $63.9 b$ \\
\hline $60 \%$ rice hulls & $166.5 c$ & $76.1 \mathrm{c}$ & $36.2 c$ & $188.6 c$ & $100.2 c$ & $44.2 c$ \\
\hline SEM & 25.4 & 18.0 & 10.5 & 24.9 & 19.2 & 14.7 \\
\hline
\end{tabular}

1 - malic dehydrogenase. 2 - glucose-6-phosphate dehydrogenase, 3 - fatty acid synthetase. $a, b-$ means with different superscripts in the same row are significantly different $(p<0.05)$. hepatic adipose enzymes in broilers are inconsistent in many reports. Rosebrough et al. (1986) observed reductions both in liver size and lipogenesis in 12-d-old broilers submitted to feed dilution from 6 to $12 \mathrm{~d}$, and Zhong et al. (1995) found that the rate of lipogenesis was lower in feed-restricted than in ad libitum fed broiler chickens up to $54 \mathrm{~d}$ of age. Conversely, Zhan et al. (2007) deprived broilers (Aconred) of feed for 4 $\mathrm{h}$ per day between 1 to $21 \mathrm{~d}$ of age, and verified that nearly full compensatory growth was achieved at 63 $\mathrm{d}$ of age, but the broilers were much fatter and had significantly elevated levels of lipid synthesis.

Zhou et al. (2000) confirmed that MDH is one NADPH-generating primary enzymes of hepatic fatty acid synthesis in growing Pekin ducks as it is in chickens, while G-6-PDH is also NADPH-generating primary enzyme in growing Pekin ducks, but not in chickens. FAS is an important biosynthetic enzyme for fatty acid synthesis. A high expression of FAS mRNA was related to increased triglyceride depot in the muscle tissue of Pekin ducks (Saez et al., 2009). Thus, the reduction of these hepatic adipose enzyme activities in the present study may explain the reduced fat accumulation in the carcass and in breast meat. Because the control of lipid accumulation within the cells depends upon the balance between synthesis and degradation of triglycerides inside the body, the effect of early feed restriction on lipid metabolism should be further studied.

\section{CONCLUSION}

Ducks are fatter, gain weight faster at an early age, and present worse feed conversion ratio than chickens. However, there are few studies on early feed restriction in ducks. According to the results of the present study, diluting the diet of Pekin ducks with $40 \%$ rice hulls in the period of 8 to $14 \mathrm{~d}$ of age clearly altered growth performance and fat deposition, and allowed nearly full compensatory growth at 42 day of age. The reduced feed: gain and lower fat content of carcass as well as the maintenance of breast meat yield obtained with diet dilution may benefit duck production and consumer's health. The mechanism of compensatory growth may be related to the evident reduced levels of lipid synthesis that occurred after feed dilution until market age. Diluting the diet of Pekin ducks from 8 to $14 \mathrm{~d}$ of age with $60 \%$ rice hulls significantly reduced body weight at market age. 


\section{REFERENCES}

Adeola O. Review of research in duck nutrient utilization. International Journal of Poultry Science 2006; 5(3):201-218.

AOAC. Official Methods of Analysis. $14^{\text {th }}$ ed. Arlington: Association of Official Analytical Chemists; 1984.

Cabel MC, Waldroup PW. Effect of different nutrition-restricted programs early in life on broiler performance and abdominal fat content. Poultry Science 1990; 69:652-660.

Downs KM, Lien RJ, Hess JB, Bilgili SF, Dozier WA. The effects of photoperiod length, light intensity, and feed energy on growth responses and meat yield of broilers. Journal of Applied Poultry Research 2006; 15:406-416.

FAO. Poultry meat and eggs: agribusiness handbook. Viale delle Terme di Caracalla; 2010.

Gibson DM, Lyons RT, Scott DF, Muto Y. Synthesis and degradation of the lipogenic enzymes of rat liver. Advances in Enzyme Regulation 1972; 10:187-204.

Govaerts T, Room G, Buyse J, Lippens M, De Groote G, Decuypere E. Early and temporary quantitative food restriction of broiler chickens. 2. Effects on allometric growth and growth hormone secretion. British Poultry Science 2000; 41:355-362.

Hall AD, Martin DM. Where next with duck meat production? International Hatchery Practice 2006; 20(6):7-8.

Hassanabadi A, Nassiri Moghaddam H. Effect of early feed dilution on performance characteristics and serum thyroxin of broiler chickens. International Journal of Poultry Science 2006; 5:1156-1159.

Hillgartner FB, Salati LM, Goodridge AG. Physiological and molecular mechanisms involved in nutritional regulation of fatty acid synthesis. Physiological Research 1995; 75:47-76.

Kersten S. Mechanisms of nutritional and hormonal regulation of lipogenesis. Embryo Reproduction 2001; 21:282-286.

Khetani TL, Nkukwana TT, Chimonyo M, Muchenje V. Effect of quantitative feed dilution on broiler performance. Tropical Animal Health and Production 2008; 41:379-384.

Lippens M, Room G, De Groote G, Deᄀcuypere E. Early and temporary quantitative food restriction of broiler chickens. 1. Effects performance characteristics, mortality and meat quality. British Poultry Science 2000; 41:343-354.

Lippens M, Huyghebaert G, Van Tuyl O, De Groote G. Early and temporary qualitative, autonomous feed dilution of broiler chickens. Effects on performance characteristics, mortality, carcass and meat quality. Archiv Fur Geflugelkunde 2002; 67:49-56.

Lohr GW, Waller HD. Glucose-6-phosphate dehydrogenase. Bergmeyer H $U$, editor. Methods of enzymatic analysis. New York: Academic Press; 1974. p. 636-649.

McMurtry JP, Rosebrough RW, Plavnik I, Cartwright Al. Influence of early plane of nutrition on enzyme systems and subsequent tissue deposition. Proceedings of the $12^{\text {th }}$ Internataional Symposium Biomechanism Regulating Growth and Development;1988; Dordrecht. The Netherlands; 1988. p.329-341.

Mohebodini H, Dastar B, Shams Sharg M, Zerehdaran S. The Comparison of early feed restriction and meal feeding on performance, carcass characteristics and blood constituents of broiler chickens. Journal of Animal and Veterinary Advances 2009; 8:2069-2074.
Nielsen BL, Litherland M, Nøddegaard F. Effect of qualitative and quantitative feed dilution on the activity of broiler chickens. Applied Animal Behaviour Science 2003; 83:309-323.

Nutrient Requirements of Poultry. $9^{\text {th }}$ ed. Washington: National Academy Press; 1994

Ochoa S. Malic enzyme. In: Colowick SP, Kaplan NO, editor. Methods in enzymology. New York: Academic Press; 1955. 739-741.

Plavnik I, Hurwitz S, Barash $H$. The effect of feed restriction on the growth, feed conversion and fattening of Pekin ducks. Nutrition Reports International 1982; 25:907-911.

Plavnik I, Hurwitz S. The performance of broiler chickens during and following a severe feed dilution at an early age. Poultry Science 1985; 64:348-355

Plavnik I, Hurwitz S. Performance of broiler chickens and turkey poults subjected to feed restriction or to feeding of low-protein or low-sodium diets at an early age. Poultry Science 1990; 69:945-952.

Rezaei M, Teimouri A, Pourreza J, Syyahzadeh H, Waldroup PW. Effect of diet dilution in the starter period on performance and carcass characteristics of broiler chickens. Journal of Central European Agriculture 2006; 7(1):63-70.

Rincon MU, Leeson S. Quantitative and qualitative feed dilution on growth characteristics of male broiler chickens. Poultry Science 2002; 81:679688

Rosebrough RW, Steel NC, Mcmurtry JP, Plavnik I. Effect of early feed restriction in broilers. II. Lipid metabolism. Growth 1986; 50(2):217-227.

Saez G, Davail S, Gentes G, Hocquette JF, Jourdan T, Degrace P, Baeza E. Gene expression and protein content in relation to intramuscular fat content in Muscovy and Pekin ducks. Poultry Science 2009; 88:23822391.

SAS Institute. Statistical analysis system proprietary software. Release 8.1 Cary; 2000

Siregar AP, Farrell DJ. A comparison of the energy and nitrogen metabolism of fed ducklings and chickens. British Poultry Science 1980; 21:213-227.

Tan BJ, Ohtani S. Effect of different early feed restriction regimens on performance,carcass composition, and lipid metabolism in male duck. Animal Science Journal 2000; 71(6):586-593

Tolkamp BJ, Sandiland V, Kyriazakis I. Effects of qualitative feed restriction during rearing on the performance of broiler breeders during rearing and lay. Poultry Science 2005; 84:1286-1293.

Tumova E, Skrivan M, Skrivanova V, Kacerovska L. Effect of early feed restriction on growth in broiler chickens, turkeys and rabbits. Czech Journal Animal Science 2002; 47:418-428

Wilson PN, Osbourn DF. Compensatory growth after undernutrition in mammals and birds. Biological Reviews 1960; 35:324-363.

Yu MU, Robinson FE, Clandinin MT, Bodnar L. Growth and body composition of broiler chickens in response to different regimens of feed dilution. Poultry Science 1990; 69:2074-2081.

Zhan XA, Wang M, Ren H, Zhao RQ, Li JX, Tan ZL. Effect of early feed restriction on metabolic programming and compensatory growth in broiler chickens. Poultry Science 2007; 86:654-660.

Zhong C, Nakaue HS, Hu CY, Mirosh LW. Effects of full feed and early feed restriction on broiler performance, abdominal fat level, cellularity, and 
fat metabolism in broiler chickens. Poultry Science 1995; 74:1636-1643.

Zhou CH, Ohtani S, Tanaka Kl. Carcass composition parts proportion and fat deposition of meat-type growing ducks. Japanese Poultry Science 2000; 37:357-364

Zubair AK, Leeson S. Effect of early feed restriction and realimentation on heat production and changes in size of digestive organs of male broilers. Poultry Science 1994; 73:529-538.

Zubair AK, Leeson S. Changes in body composition and adipocyte cellularity of male broilers subjected to varying degrees of early-life feed restriction. Poultry Science 1996; 75:719-728. 